\title{
Hypertrophic olivary degeneration
}

\author{
Stephanie Anastasi, Reuben Grech
}

Radiology, Mater Dei Hospital, Msida, Malta

\section{Correspondence to} Dr Stephanie Anastasi, Steffianastasi@gmail.com

Accepted 7 July 2017

\section{DESCRIPTION}

A 30-year-old man underwent MRI of the internal auditory meatus as a routine follow-up after excision of a large left vestibular schwannoma, 2.5 years previously. MRI images showed an incidental finding of left hypertrophic olivary degeneration (figure 1 and figure 2). This phenomenon occurs as a result of Wallerian degeneration of

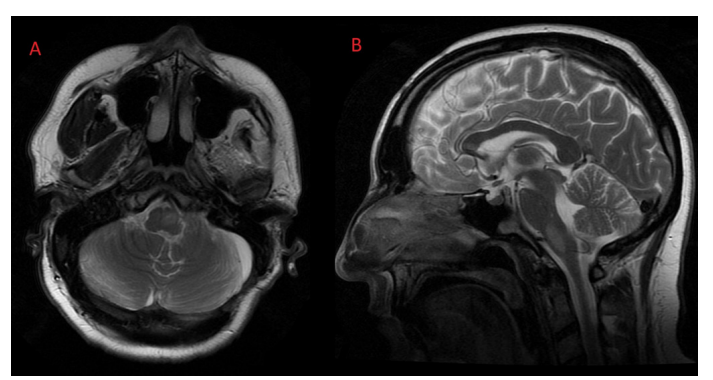

Figure 2 Axial (panel A) and sagittal (panel B) T2-weighted images demonstrating a well-defined hyperintense, expansile lesion centred in the left olivary nucleus. Features are consistent with HOD secondary to a lesion in the triangle of Guillain and Mollaret (Figure 1). HOD, hypertrophic olivary degeneration.

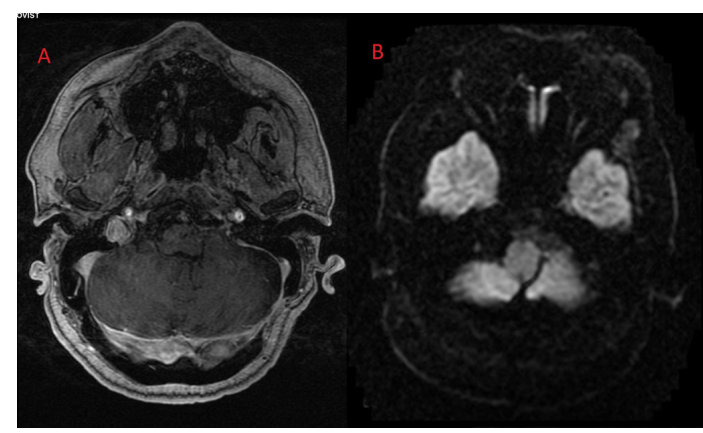

Figure 3 The medullary lesion does not enhance following contrast administration (panel A) and does not restrict diffusion (panel B). Differential diagnoses of HOD include infarction, neoplasms and demyelination. HOD, hypertrophic olivary degeneration.

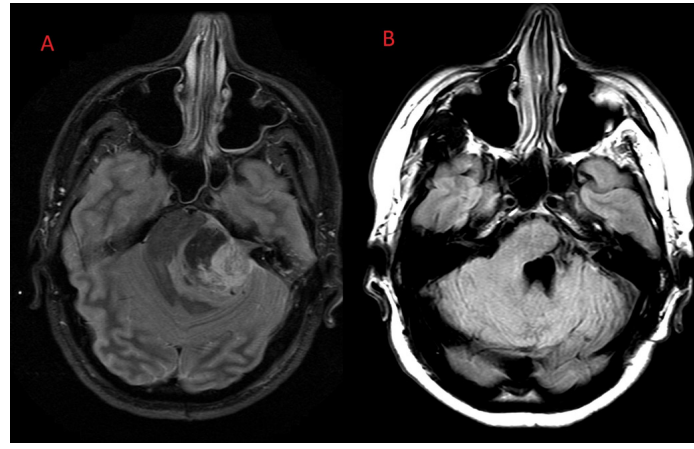

Figure 1 Axial T2-weighted sequence showing intratumoral haemorrhage within a large left cerebellopontine angle lesion in keeping with a vestibular schwannoma (panel A). Axial fluid attenuated inversion recovery (FLAIR) image through the posterior fossa after 6 months demonstrating atrophic changes and haemosiderin deposition in the left middle cerebellar peduncle (panel B).

the olivary nucleus secondary to a lesion in the triangle of Guillain and Mollaret, also known as the dento-rubro-olivary pathway (figure 3 ). The differential diagnoses of hypertrophic olivary degeneration include infarction, infection, neoplasms and demyelination. Differentials can be excluded by the absence contrast enhancement (figure 2).

Contributors SA wrote the attached case report under the guidance of RG, consultant radiologist, who encountered the images from routine practice.

Competing interests None declared.

Patient consent Obtained.

Provenance and peer review Not commissioned; externally peer reviewed.

(c) BMJ Publishing Group Ltd (unless otherwise stated in the text of the article) 2017. All rights reserved. No commercial use is permitted unless otherwise expressly granted.

\section{REFERENCES}

1 Sarawagi R, Murugesan A. Hypertrophic olivary degeneration - a report of two cases. J Clin Imaging Sci 2015;5:8.

\section{Learning points}

- The degeneration occurring in hypertrophc olivary degeneration (HOD) is unique, as it causes hypertrophy rather than atrophy, a change which may last up to 3-5 years. ${ }^{1}$ MRI findings vary according to the stage of the degenerative process, most commonly going through three stages on T2-weighted images: hyperintensity without hypertrophy, followed by hyperintensity with hypertrophy and ending with hyperintensity without hypertrophy. ${ }^{2}$

To cite: Anastasi S, Grech R. BMJ Case Rep Published Online First: [please include Day Month Year]. doi:10.1136/bcr-2017220212

- HOD may be easily mistaken for an infarct or a neoplasm, particularly if the history of the patient is unknown. ${ }^{1}$ Diffusion images and contrast studies help differentiation.

- The initial event could be due to a tumour, infarct or trauma affecting the dento-rubro-olivary pathway, although it most commonly occurs following haemorrhage in a patient with hypertension. ${ }^{2}$ 


\section{Images in...}

2 Bruno MK. Hypertrophic Olivary Degeneration. Arch Neurol 2012;69:274.

Copyright 2017 BMJ Publishing Group. All rights reserved. For permission to reuse any of this content visit http://group.bmj.com/group/rights-licensing/permissions.

BMJ Case Report Fellows may re-use this article for personal use and teaching without any further permission.

Become a Fellow of BMJ Case Reports today and you can:

- Submit as many cases as you like

- Enjoy fast sympathetic peer review and rapid publication of accepted articles

- Access all the published articles

- Re-use any of the published material for personal use and teaching without further permission

For information on Institutional Fellowships contact consortiasales@bmjgroup.com

Visit casereports.bmj.com for more articles like this and to become a Fellow 